\title{
Blood Urea Nitrogen To Creatinine Ratio Measurement
}

National Cancer Institute

\section{Source}

National Cancer Institute. Blood Urea Nitrogen To Creatinine Ratio Measurement. NCI

Thesaurus. Code C74753.

The determination of the ratio of blood urea nitrogen compared to creatinine present in a sample. The measurement may be expressed as a ratio or percentage. 